Dariusz Prokopowicz

Cardinal Stefan Wyszyński University

in Warsaw, Poland

ORCID iD: 0000-0001-6383-916X

AnNa GOŁEBIOWSKA

Main School of Fire Service in Warsaw,

Poland

ORCID iD: 0000-0003-0478-5047
DOI: $10.13166 / j m s / 143848$

JOURNAL OF MODERN

SCIENCE TOM 2/47/2021

\title{
INCREASE IN THE INTERNETIZATION OF ECONOMIC PROCESSES, ECONOMIC, PANDEMIC AND CLIMATE CRISIS AS WELL AS CYBERSECURITY AS KEY CHALLENGES AND PHILOSOPHICAL PARADIGMS FOR THE DEVELOPMENT OF THE 21ST CENTURY CIVILIZATION
}

\begin{abstract}
This article describes the multifaceted issues of the increase in the Internetisation of economic processes, the economic, pandemic and climate crisis, and cybersecurity as key challenges and philosophical paradigms for the development of the 21st century civilization. The main aim of the research was to diagnose the main determinants and correlations between the above-mentioned crises and to identify key problems in the development of civilization. The applied research methods are, first of all, the analysis of the problem carried out on the basis of a literature review and original retrospective and prospective analyzes of the subject matter under study. The conducted research shows the following theses and conclusions: The SARS-CoV-2 (Covid-19)
\end{abstract}


coronavirus pandemic has caused a modification of the ongoing globalization processes, shortening of international supply logistics chains, acceleration of digitization and internetization of remote communication and economic processes. The pandemic also accelerated the development of electronic internet banking, including mobile banking. Accordingly, the importance of improving cybersecurity techniques is also growing. The pandemic triggered a deep economic crisis in 2020 and a recession in the global economy as well. In order to limit the development of the economic crisis, governments of many countries have applied public financial aid programs offered to economic entities of selected industries and sectors of the economy. Various anti-crisis state aid programs were used as part of interventionist socio-economic, fiscal and monetary policies. During the pandemic, there was also an increase in the general social pro-environmental awareness of citizens and the possibility of accelerating the processes of pro-ecological transformation of the classic economy to a zero-emission, sustainable, green circular economy has opened up. Due to the growing importance of environmental policy and the increase in the scale of the implementation of the sustainable development goals, the probability of a global climate crisis that might appear at the end of the current 21 st century has been reducing.

KeYwords: Coronavirus, Covid-19, digitization, economy, economic crisis, climate crisis, sustainable development, globalization, cybersecurity

\section{THE SARS-COV-2 (COVID-19) CORONAVIRUS PANDEMIC MODIFIES GLOBALIZATION PROCESSES}

The current globalization processes are progressing mainly in several areas, i.e. economic, information, technological and social globalization, the unification of cultural patterns, etc (Matosek, Prokopowicz, 2018, pp. 31-32). The socio-economic globalization that has been taking place for several decades has made the world seem bigger, while information globalization, mainly due to the development of the Internet, made the world seem smaller, which is symbolized by defining the world as the so-called global village (Prokopowicz, 2012 , pp. 39-40). On the other hand, the processes of economic, information, technological, globalization etc. cause a gradual increase in the flow of information and technology between countries (Harold, 2010, p. 38). An 
important role in this matter is played by multinational corporations, and within them international corporations, including technology, production, information services, Internet, financial corporations etc., which invest in other countries, carry out direct investments, create new production plants and technological and logistic centers etc. in other countries and thus the technology is transferred from country to country. Winona LaDuke once said that "Corporations do not have the right to make political decisions", thereby implying that the political influence of multinational corporations in certain countries, particularly smaller emerging economies, characterized by lower incomes and less endowment of different categories of capital, may be big, maybe too big (Górski, 2013, p. 47). This issue is a moot point. However, the great importance of large, internationally operating enterprises, corporations, including the largest technological Internet companies, as one of the key determinants of the processes of economic, information, technological globalization, etc (Gwoździewicz, Prokopowicz, 2016a, pp. 65-66) currently taking place, is beyond dispute.

Chart 1.

Daily new confirmed COVID-19 cases per million people. Shown is the rolling 7-day average. The number of confirmed cases is lower than the number of actual cases; the main reason for that is limited testing.

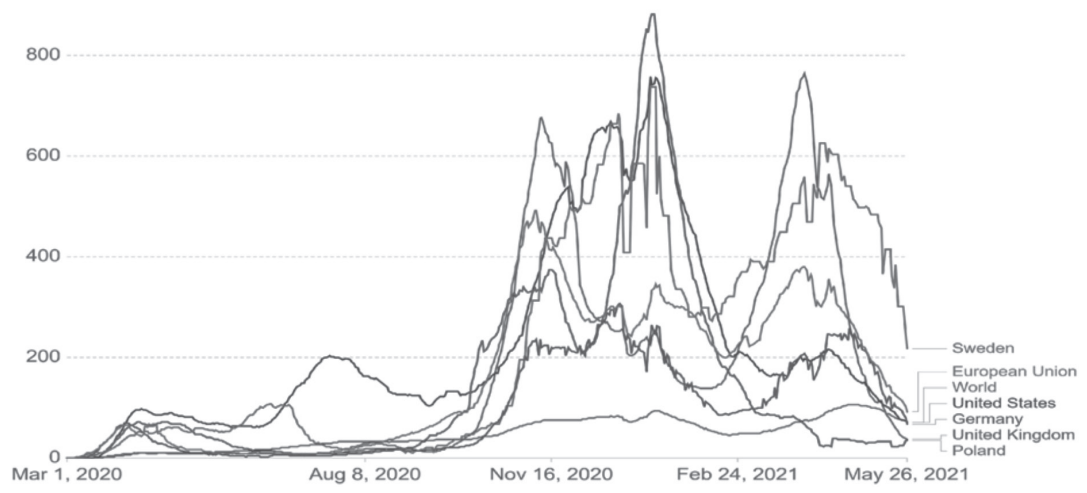

Source: H. Ritchie, E. Ortiz-Ospina, D. Beltekian, E. Mathieu, J. Hasell, B. Macdonald, Ch. Giattino, C. Appel, L. Rodés-Guirao, M. Roser (2021). Coronavirus Pandemic (COVID-19), Published online at OurWorldInData.org., Online Resource (Retrieved from: https://ourworldindata.org/coronavirus), for: Johns Hopkins University CSSE COVID-19 Data. 
The SARS-CoV-2 (Covid-19) coronavirus pandemic can be studied in the context of various aspects of globalization processes. On the one hand, the pandemic is global, although it cannot be ruled out that through constant mutations, new, regional, continental types of Coronavirus strains are arising. However, when studying the impact of the SARS-CoV-2 coronavirus on the global economy and economies of individual countries, there are many disintegrating aspects and factors that act opposite to the traditional processes of economic globalization. The coronavirus pandemic may significantly modify the processes of economic, technological and information globalization that have been going on for years. The processes of information and technological globalization may accelerate due to the increase in digitization of communication, manufacturing economic processes, etc (Dmowski, Prokopowicz, 2010, pp. 285-286). On the other hand, international logistics chains and corporate capital ties may change. Such processes appeared at the beginning of the pandemic development (Golczak, Golinowski, Kamycki, Lewandowski, Pająk, Płaczek, Prokopowicz, Wesołowski, 2020, pp. 93-94).

One of the factors that significantly reduces the scale of production is not only the rapidly declining demand for specific services and products, but also situations where production processes are suspended for specific ranges of components, semi-finished products, spare parts, in countries where the scale of coronavirus infections is high. As a result, logistic chains broke, certain components and semi-finished products were not delivered on time to plants and assembly plants, where final products are manufactured in other countries. As on a global scale, internationally operated transport, distribution and supply logistics, many logistics chains are composed of at least several stages of intermodal transport, the risk of delays in delivering the necessary assortment for final production carried out in other countries is high. Therefore, the risk of maintaining the continuity of business processes and maintaining production at an optimal level increases. As a result of these problems, many companies decide to transfer the production of necessary components and semi-finished products to other countries, to other economic regions of the world, to other continents in order to shorten and simplify intermodal, international logistics chains of transport of a specific range of manufactured semi-finished products or final products. 
Therefore, if, due to the SARS-CoV-2 pandemic, international, including intermodal logistics chains have been temporarily interrupted, some production processes may be transferred to other countries. This may lead to a situation where international corporations that in previous years divided their production processes into stages carried out in plants and factories located in other countries, may return to the concept of concentrating all production processes in the same countries, in the countries where the company is located, or in the countries that are much closer to each other, due to problems related to supply logistics. This can lead to a situation where many factories will return from developing countries to developed countries despite slightly or much higher production costs (Zielińska-Głębocka, 2012, p. 73). In this way, the risk of supply, supply logistics, etc. will be significantly reduced. If this type of international economic processes is carried out on a large scale in the coming months and years, then some aspects of the processes of economic globalization will regress. In connection with the above, the processes of globalization may undergo significant modifications under the influence of the SARS-CoV-2 coronavirus pandemic. 
Figure 1.

Stay-at-home requirements during the COVID-19 pandemic, May 27, 2021. There may be sub-national or regional differences in restrictions. The policy categories shown may not apply at all sub-national levels. A country is coded as having these restrictions if at least some sub-national regions have implemented them.

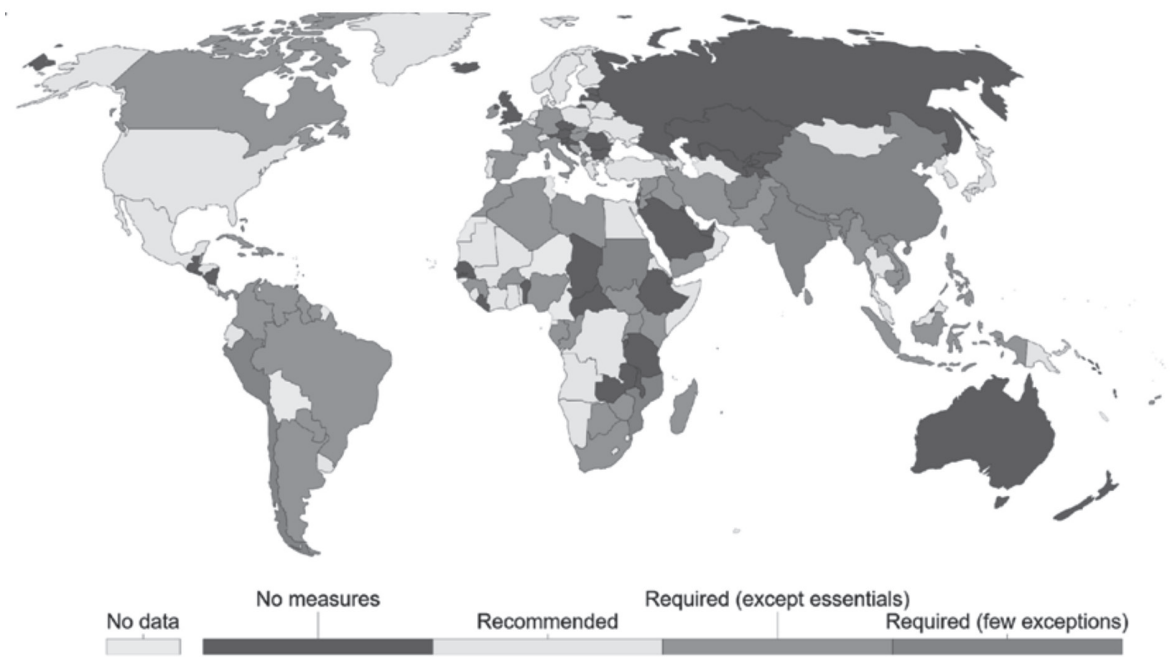

Source: H. Ritchie, E. Ortiz-Ospina, D. Beltekian, E. Mathieu, J. Hasell, B. Macdonald, Ch. Giattino, C. Appel, L.Rodés-Guirao, M. Roser (2021). COVID-19: Stay-at-Home Restrictions, for: Hale, Angrist, Goldszmidt, Kira, Petherick, Philips, Webster, Cameron-Blake, Hallas, Majumdar, Tatlow (2021). A global panel database of pandemic policies (Oxford COVID-19 Government Response Tracker), in: Nature Human Behaviour, last updated 27 May, 2021 (https://ourworldindata.org/covid-stay-home-restrictions).

The multifaceted effects of the aforementioned globalization processes also appear in the functioning of both national economic and financial systems and economic entities operating internationally. The scale of the impact of globalization processes on individual companies and corporations operating nationally or internationally is also determined by the amendments to the content of the legal norms that apply to these entities (Gwoździewicz, D. Prokopowicz, 2015, pp. 205-206). 


\section{ACCELERATION OF THE Digitization AND INTERNETIZATION OF ECONOMIC PROCESSES AND REMOTE COMMUNICATION OF PUBLIC INSTITUTIONS}

The SARS-CoV-2 (Covid-19) coronavirus pandemic accelerated the digitization and Internetization of remote communication and economic processes. The increase in the scale of digitization of the economy is also achieved through the development of e-learning, the implementation of ICT information technologies and Internet applications to economic, financial (Kołodko, Mihm, Roubini, 2011, p. 64), research, education processes, etc. An increase in the digitization of economic, information, etc. processes carried out in economic entities, public and financial institutions (Przybylska-Kapuścińska ed., 2013, p. 81) is also the effect of this type of pandemic crises. Since the first wave of the pandemic, i.e. since March 2020, there has been a significant acceleration in the development of e-commerce, e-banking, e-logistics, etc. Many small companies, including service companies subject to lockdown, increased the scale of their operations on the Internet, transferred a significant part or all of their sales to the Internet. Many companies from the SME sector created sales platforms for their products and/or services on their websites only during the pandemic period. In 2020, the development of the SARS-CoV-2 (Covid-19) coronavirus pandemic was the main factor behind the decline in international trade, international capital flows and other factors of production, international economic cooperation, etc.

However, the decline in sales revenues and profits does not apply to all enterprises and industries. Already during the first wave of the pandemic, i.e. in April 2020, it could be observed that there are sectors in which companies record increase in sales. For example, companies that develop sales via the Internet, develop e-commerce, commercial networks that offer sales via the Internet, companies that produce an assortment of anti-pandemic and pharmaceutical products, etc. also online new media, including social media portals, are a type of media and at the same time a type of companies that, despite potential decline in advertising sales revenues, may record a relative increase in the importance and share in the media market. 
Therefore, digitization of the economy is currently taking place in many areas of economic processes and in the functioning of many economic entities and public, financial and other institutions. In many industries and sectors, more and more companies develop their activities via the Internet, remotely providing their services and selling their products via e-commerce. Many companies that previously did not do this are now switching to remote, electronically conducted activities over the Internet.

Consequently, the importance of internet marketing, including viral marketing, public relations, videoconferences, etc. over the Internet, is increasing. The development of electronic banking (Białas, Mazur, 2013, pp. $82-83$ ) is also increasing, including internet and mobile banking. The share of electronic, cashless payments via the Internet and payments with electronic bank cards is increasing. Therefore, the SARS-CoV-2 coronavirus pandemic may significantly increase the share of payments made electronically in the context of all payments made in domestic economies. In addition, the ongoing technological progress may lead to an increase in the implementation of Industry 4.0 (Grzegorek, Prokopowicz, Goździewicz, 2021, pp. 127-128) technology into economic processes in the future. Therefore, in the next dozen or so years, technology, including artificial intelligence and learning machines, might replace humans in many workplaces. In the future, this may be a growing problem for labor markets and for the fiscal system. The economic downturn caused by the pandemic, including the economic recession in 2020, forced many economic entities to carry out repair and development restructuring processes in their business.

As part of remedial restructuring, the companies optimized costs, and as part of development restructuring, they implemented new technologies in order to survive the difficult period of economic downturn. Moreover, the conducted development restructuring processes strengthen the business in the context of the occurrence of similar economic crises in the future. In view of the above, the pandemic also caused an increase in the implementation of Industry 4.0 technology into economic processes, remote communication processes, etc (Dahl, Prokopowicz, Gwoździewicz, Grzegorek, 2018, s. 47-48). During the pandemic, there has been an increase in Industry 4.0 technologies such as robotics, artificial intelligence, 
machine learning, Internet of Things, cloud computing, Data Science (Prokopowicz, Gwoździewicz, 2017, pp. 32-33), Big Data Analytics (Filip, 2015, pp. 41-42), additive manufacturing, etc. These technologies are implemented, among others, into improved crisis management systems, pandemic risk management and improvement of anti-pandemic safety systems and instruments. Autonomous robots help in hospitals in the process of caring for people suffering from the Covid-19 disease, in patrolling city parks, etc. Artificial intelligence technology and learning machines are used in the development of intelligent data mining systems and in the development of avatawrs acting as call-centers and customer advisors on websites. Smart technologies are used to develop current local pandemic information systems available on smartphones.

Chart 2.

Change in visitors by category. How did the number of visitors change since the beginning of the pandemic? (Poland). This data shows how community movement in specific locations has changed relative to the period before the pandemic.

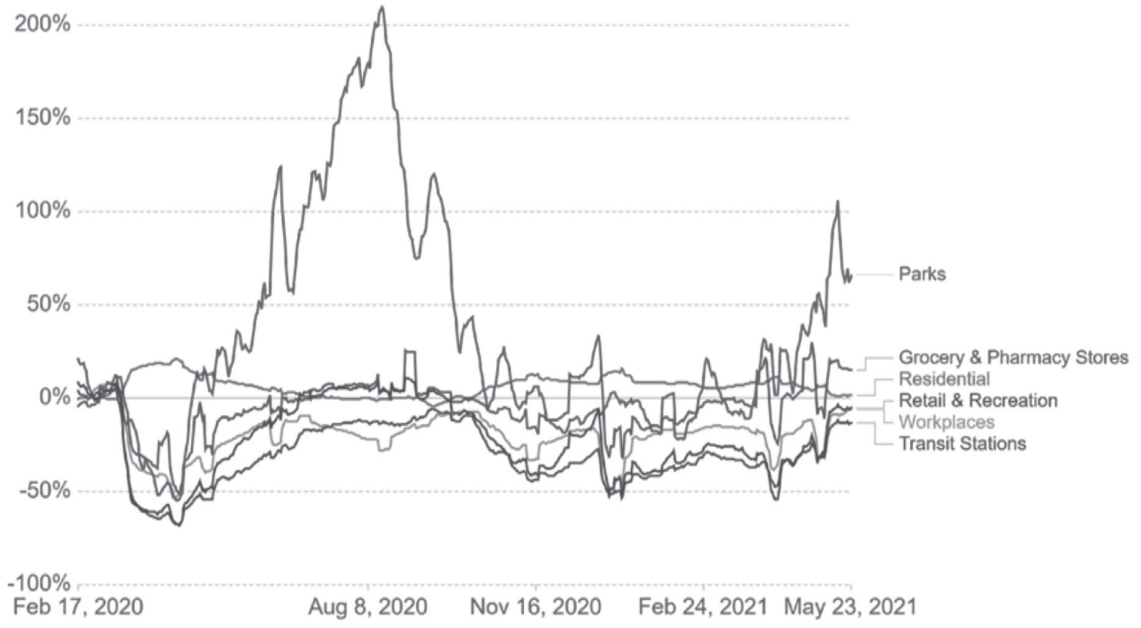

Source: H. Ritchie, E. Ortiz-Ospina, D. Beltekian, E. Mathieu, J. Hasell, B. Macdonald, Ch. Giattino, C. Appel, L. Rodés-Guirao, M. Roser (2021). Coronavirus Pandemic (COVID-19), Published online at OurWorldInData.org., Online Resource (Retrieved from: https://ourworldindata.org/coronavirus), for: Google COVID-19 Community Mobility Trends, Last updated 23 May, 2021, (https://OurWorldInData. org/policy-responses-covid). 
Despite the downturn and economic recession related to the Coronavirus pandemic, almost 56 percent companies in Poland have either maintained or accelerated their investments in digitization. In addition, 9 percent. of companies introduced new investments in the field of Industry 4.0 solutions, which were not planned before the pandemic period. Research conducted by the research company Autodesk shows that the process of implementing innovation is, according to the management of industrial companies, a way to increase the efficiency and flexibility of enterprise production $(89.1 \%)$, the possibility of increasing competitiveness (87.7\%) and the necessity to maintain a good market position (79.1\%) (Kontkiewicz - Studzińska, Cieślak, 2021). The above-mentioned studies show that technological innovations, information technologies, ICT and Industry 4.0 support also business management processes and facilitate business decision-making (Karaś, 2017, pp. 236-237).

Commercially operating business entities and banks efficiently digitize and internetize their economic processes. Digitization and Internetization of offices and public institutions is usually the challenge. This process should be carried out in accordance with the principles of corporate social responsibility (Scholtens, 2009, pp. 159-175). Despite the fact that the process of digitization and internationalization of offices and public institutions is largely determined by the implementation of technological solutions developed in the commercial sector, it is usually slower than similar processes carried out in commercial enterprises, corporations and financial institutions (Prokopowicz, Gwoździewicz, 2019, pp. 27-28). Digitization and Internetization of companies and financial and public institutions increases the effectiveness of remote communication processes, improves management processes, reduces operating costs, increases the quality of the offer of products and services and citizen service in public offices. On the other hand, improvement of cybersecurity techniques and improvement of cybersecurity risk management processes are the challenges here. 


\section{INCREASING IMPORTANCE OF CYBERSECURITY}

In view of the above, the SARS-CoV-2 (Covid-19) coronavirus pandemic accelerated also the development of electronic internet banking, including mobile banking. In this way, banks reduce operating costs and increase the profitability of customer service operations. Customers, on the other hand, choose online banking for its convenience and lower banking fees. It may be concluded from the above that when the SARS-CoV-2 (Covid-19) coronavirus pandemic expires, the current trends in the development of online electronic banking, including mobile banking, will be maintained. As for many banks the scale of electronic internet banking and mobile banking is gradually increasing compared to traditional fixed-line banking, banks spend an increasing part of their development funds on the implementation of modern ICT, Internet and Industry 4.0 information technologies into electronic internet banking systems and platforms, and on improvement of cybercrime risk management systems and improving cybersecurity systems for online transactions (Dmowski, Prokopowicz, 2006, pp. 77-78).

In recent years, mobile technologies in mobile internet banking applications have developed rapidly. Since the improvement of cybercrime risk management processes is the key issue in the development of online banking, including mobile banking, the importance of research has been growing in recent years on the possibility of building and using systems simulating various types of attacks by hackers and those carried out by cybercriminals on mobile banking applications running on operating systems installed on smartphones, including the use of selected Industry 4.0 technologies to conduct simulations and forecast analyses of the aforementioned attacks on mobile banking applications. The issue of improving the cybersecurity risk management process, the application of machine learning technologies to the aforementioned cybersecurity risk management process, analysis of the costs of systems development and ensuring a certain level of cybersecurity and development prospects for the offer of information services and mobile banking services in correlation with cybersecurity banking supervision guidelines for ensuring the optimal level of cybersecurity in the mobile banking offer and technology developing in banks (Gwoździewicz, Prokopowicz, 2016b, pp. 85-86) are also important elements of this matter. 
In addition, the key research issues related to cybersecurity in electronic internet banking include:

1. improving cybersecurity technologies in the use of websites and applications created as part of electronic, online mobile banking,

2. analysis of the possibilities to develop Industry 4.0 technology applications, including machine learning, blockchain, cloud computing, etc. in order to improve the applications used by bank customers on smartphones,

3. analysis of the improvement of the cybersecurity risk management process by expanding the functions of websites and new online information services in web applications installed on smartphones, while taking into account the costs of improving and increasing the level of cybersecurity,

4. statistics of hacking attacks and cybercriminals' attacks on these applications in relation to the financial results of online mobile banking, the development of the portfolio of customers using this type of banking, the level of customer awareness of cybersecurity, the number of successful hacker attacks into mobile banking systems and the level of financial losses caused by cyber criminals,

5. analysis of compliance with procedures and recommendations regarding the principles of the safe use of mobile banking by bank customers (Domańska-Szaruga, Prokopowicz, 2016, pp. 127-128).

In recent months, there have been more cases of cybercriminal attacks using ransomware-type viruses. These viruses encrypt access to data on disks, making the data unusable. Encryption is performed using hard-to-break encryption algorithms. After the access to data is encrypted, cybercriminals send a ransom demand to companies that have been victims of a cybercriminal attack. After paying the ransom, they hand over the decryption key.

There are not many direct links between the development of the coronavirus pandemic and the development of cybersecurity techniques and systems. On the other hand, while studying these issues, one can find indirect connections between these significantly distant areas of scientific disciplines. The development of the coronavirus epidemic and pandemic can be compared to the development of hacker and cybercriminal attacks using new types of viruses, 
Trojan horses, etc., which are often spread via email communication. In my articles and in the monograph "Legal and Social Aspects of Cybersecurity", I described the issues of cybercrime and cybersecurity on the example of the analysis of attacks carried out mainly on computers and other devices connected to the Internet with the use of ransomware viruses (Gwoździewicz, Prokopowicz, 2020, pp. 63-64).

In addition, the issue of various pieces of information that has not been confirmed by scientific data, which appear on popular social media portals (e.g. Facebook, Tweeter, Instagram, TikTok, ...) regarding various aspects coronavirus and the Covid-19 disease it causes, including, first and foremost, information on unproven therapies and theories on key factors in the development of the pandemic (Prokopowicz, Gwoździewicz, 2016, pp. 397-398), is another example of indirect, interdisciplinary connection between the issues of the Coronavirus pandemic and cybersecurity. Deliberate and conscious disinformation conducted on these websites on such an important topic as the pandemic development and treatment therapies can be interpreted and analyzed in the context of the problem of imperfection of algorithms analyzing the content of posts, entries, comments, etc. entered by users of social media portals (Matosek, Prokopowicz, 2017, pp. 225-226). Of course, the problem is complex and multifaceted, because this type of technical analytical systems which are the basis for the verification and control of content posted by users of social media portals also applies to the issue of open access to knowledge, liberalization of publishing and expressing individual views, and active use of information services available on social media for citizens. However, this type of analysis of correlation between the issue of the coronavirus pandemic and cybersecurity is characterized by a significantly extensive interdisciplinarity.

Analyses of correlation occurring between the SARS-CoV-2 coronavirus, which caused great social, medical, economic, financial and mental costs, etc., and particularly dangerous types of computer viruses (such as ransomware viruses) which also generate high costs, are much closer, more analogous but also interdisciplinary. The above-mentioned additional costs are generated in various aspects, both for entities whose computers have been attacked with this type of virus, and for the costs of improving cybersecurity systems and techniques borne by individuals, companies or institutions, and as part of 
the necessary activity of increasing the level of cybersecurity carried out by institutions responsible for cyber, Internet and information security on the national scale. In addition, the scale of international development of these problems is also a factor of analogy, because both the SARS-CoV-2 coronavirus pandemic and many dangerous computer viruses that spread mainly through e-mail communication are global in nature. Therefore, it is necessary to develop international cooperation in order to effectively limit the scale and pace of development of both attacks of biological viruses (e.g. the coronavirus) and attacks of IT-Internet viruses (e.g. ransomware viruses).

\section{THE ECONOMIC CRISIS CAUSED BY THE SARS-COV-2 (COVID-19) CORONAVIRUS PANDEMIC}

In the past, major pandemics have usually not been main triggering factors of economic and/or financial crises (Matysek-Jędrych ed., 2011, pp. 93-94). In the last 100 years, specific economic problems, errors in making investment decisions, unreliable adherence to business and banking procedures, failure to comply with the principles of financial and credit risk management, etc (Wereda, Prokopowicz, Domańska-Szaruga, 2018, pp. 268-269) have been the sources of the greatest financial and economic crises. Besides, in the past, several dozen or more years ago, epidemics were confined to cities, regions and parts of continents. In contrast, the SARS-CoV-2 (Covid-19) coronavirus pandemic has spread rapidly globally due to the widespread communication globalization, globalization of transport, tourism, etc.

The large scale of the pandemic development resulted in a decline in economic activity, a decline in the production of many companies, a decline in employment and a panic of asset sales on capital markets. The current economic crisis is therefore completely different from the previous ones in terms of its sources. Paradoxically, there are more similarities with previous crises in terms of the applied instruments of state intervention, including anti-crisis socio-economic policy programmes, including the fiscal policy of the Ministry of Finance or the Ministry of the Treasury, and the monetary policy of the central bank. 
Lots of macroeconomic data show that the impact of the SARS-CoV-2 coronavirus pandemic on the global economy was considerable in 2020. The economy experienced a deep recession during the first wave of the pandemic in the second quarter of 2020. In 2020 it was no longer the so-called trade wars that were the main factor behind the decline in international trade, in international capital flows and other factors of production and in international economic cooperation (Filip, Komorowski, 2016, pp. 67-68).

Chart 3.

Correlation of selected keywords (analysis from Google Trends).
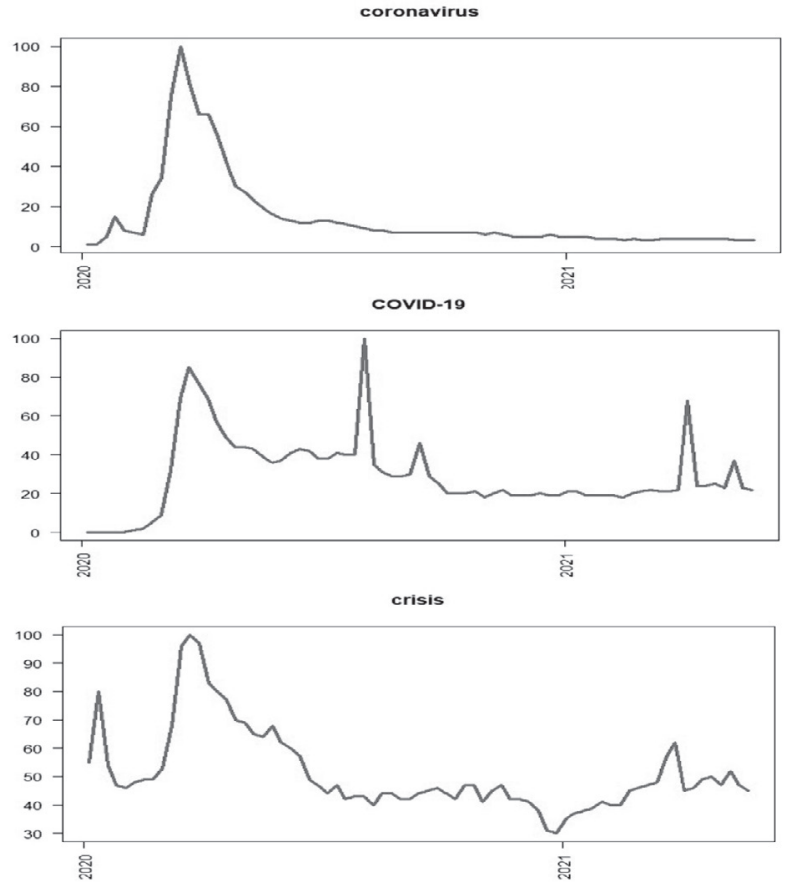

Source: Own study. 
In 2020, the main factor behind the decline in international trade and capital flows was the development of the coronavirus pandemic. The pandemic has also affected logistics processes and chains. For example, if due to the SARS-CoV-2 pandemic, international and intermodal logistics chains were temporarily disrupted as a result some production processes may be shifted to other countries. This may lead to a situation where international corporations, which in previous years divided their production processes into stages carried out in plants and factories located in different countries, may now return to the concept of concentrating all manufacturing processes in the same countries, in the countries where the company is located, or in countries that are much closer to each other due to problems related to supply logistics. In such a situation, many factories will return from developing countries to developed countries despite somewhat or much higher production costs (Prokopowicz, 2016, pp. 22-323). In this way, the risk of supply, supply logistics, etc. will be significantly reduced. If such international economic processes are carried out on a large scale in the coming months and years, the processes of economic globalization will reverse. According to the authors of this article, the current coronavirus pandemic may potentially cause the most changes in logistics in the situation of long, complex, intermodal, international logistics chains of supply and sourcing. Apart from that, the Coronavirus pandemic accelerated the processes of digitization of the economy. Since the beginning of the pandemic more and more companies in many industries and sectors have been expanding their activities via the Internet, providing their services remotely and selling their products via e-commerce. 
Chart 4.

Retail and recreation: How did the number of visitors change since the beginning of the pandemic? This data shows how the number of visitors to places of retail and recreation has changed relative to the period before the pandemic. This includes places like restaurants, cafés, shopping centers, theme parks, museums, libraries, movie theaters.

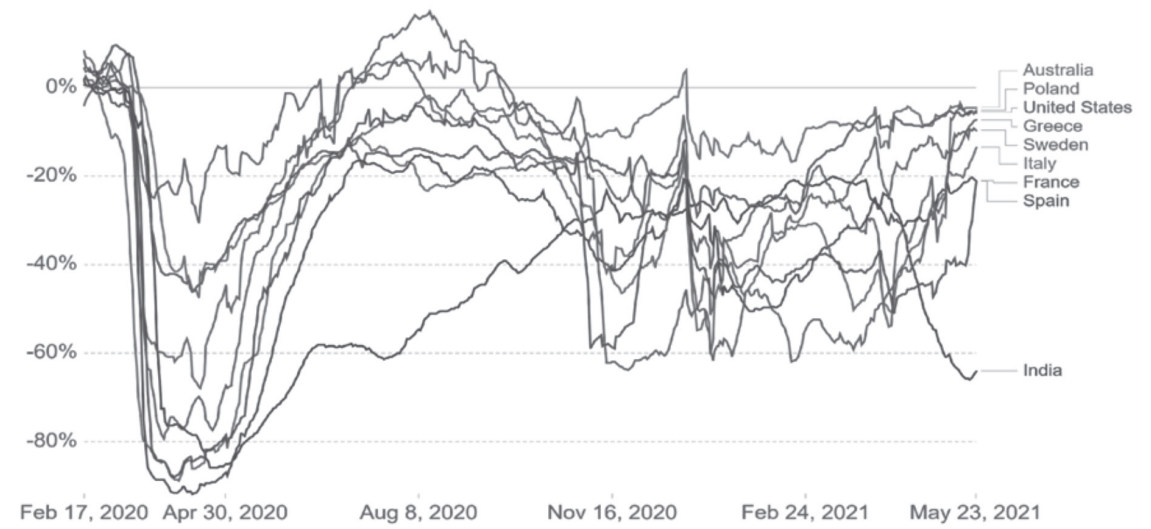

Source: H. Ritchie, E. Ortiz-Ospina, D. Beltekian, E. Mathieu, J. Hasell, B. Macdonald, Ch. Giattino, C. Appel, L. Rodés-Guirao, M. Roser (2021). Coronavirus Pandemic (COVID-19), Published online at OurWorldInData.org., Online Resource (Retrieved from: https://ourworldindata.org/coronavirus), for: Google COVID-19 Community Mobility Trends, Last updated 27 May, 2021, (https://OurWorldInData. org/coronavirus).

Many companies that had previously not done this, have switched to remote operations, conducted electronically via the Internet since the second quarter of 2020. The importance of Internet marketing, including viral marketing and Real-Time marketing conducted on social media portals, has increased. The development of electronic banking is also increasing, including internet and mobile banking. Therefore, traditional logistics can also be increasingly replaced by logistic business models in which some or all of the components of the logistics processes are carried out via the Internet. In such a situation, the importance of e-logistics is growing (Wołowiec, Szybowski, Prokopowicz, 2019, pp. 232-233). In addition, the impact of the current coronavirus pandemic on the banking sectors of individual countries is usually also large. This is mainly an indirect impact on commercial banking-mainly secondary, cyclical impact, resulting from the decline in economic activity in other sectors and branches 
of the economy (Piech, Wierus, 2012, p. 93). On the other hand, the influence of central banking stabilizing economic processes in the banking sector and, indirectly, in the entire economy, is dependent on the real scale of the central bank's independence from other public and government institutions and on whether the national or international currency functions in a given country. If there is an international currency in the country, then the scope of application of specific monetary policy instruments used as anti-crisis policy tools is much smaller compared to the situation where the country has a domestic currency and the central bank has all the tools of full monetary policy. This type of full monetary policy is applied in Poland. Especially in the area of the interventionist, anti-crisis monetary policy of the National Bank of Poland, the instrument of direct purchase of subsequent Treasury bond issues by the central bank has been used since the first wave of the pandemic, for the first time on a larger scale. It was one of the key anti-crisis instruments of state intervention in Poland, thanks to which it was possible to introduce additional amounts of money into the economy, stop the rise in unemployment and decline in economic activity of many companies and enterprises, and stop the deepening of the recession (Golczak, Golinowski, Kamycki, Lewandowski, Pająk, Płaczek, Prokopowicz, Wesołowski, 2020, pp. 94-95). However, this type of anti-crisis state interventionism may generate an increase in systemic credit risk, as discussed in the next chapter of this article.

\section{ANTI-CRISIS AND PRO-DEVELOPMENT SOCIO-ECONOMIC AND FISCAL POLICY}

The state has been conducting anti-crisis and pro-development socio-economic, fiscal, budget, sectoral and also monetary policies from the first wave of the pandemic in order to counteract the development of the economic recession in 2020. In the past, however, there were situations where the credit policy of commercial banks was too lenient, systemic credit risk was growing and credit risk management systems were ineffective as part of an active, pro-development, interventionist socio-economic policy, and this led to a financial and economic crisis (Prokopowicz, 2020a, pp. 27-28). This situation led to the 
appearance of the 2008 financial crisis in the Anglo-Saxon banking system (Szybowski, Prokopowicz, Gwoździewicz, 2016, pp. 139-150). Currently, the systemic risks of the debt of the state finance system are also growing due to the anti-crisis socio-economic policy whose aim is to limit the development of the economic recession caused by the coronavirus pandemic. Significant increases in debt levels are often the source of the financial and economic crisis. There are many examples confirming this thesis (Nawrot, 2009, p. 58). In the past, significant increases in debt levels caused serious financial and economic problems for many economic actors, including financial institutions and other types of entities, organizations and public institutions (Prokopowicz, 2018, pp. 156-157).

Serious financial problems also led to the permanent loss of financial liquidity and the declaration of insolvency of a specific economic entity, company, corporation, bank, etc. This problem concerns not only entities examined in the microeconomic perspective, i.e. individual economic entities. This problem concerned more than once the macroeconomic approach, when the high debt of the state's public finances led to the declaration of financial insolvency of the state, i.e. e.g. the announcement of the state's insolvency towards creditors of foreign financial institutions that had previously granted loans or purchased Treasury bonds. The authors of this article examine this issue in the context of the analysis of the sources of the global financial crisis that emerged in the fall of 2008 (Prokopowicz, 2020a, pp. 21-22). As the crisis unfolded many companies, corporations and banks had serious financial problems that were caused by a strong increase in debt. If the state had not launched anti-crisis rescue programs for banks and corporations, many of these entities would have collapsed and the global financial crisis of 2008 would have been even more serious than it was (Prokopowicz, Gwoździewicz, 2018, pp. 217-218).

On the other hand, the launch of these rescue programs resulted in a significant increase in the debt of public finances in many countries. This elevated level of public debt persists to the present day in many countries. In some countries, this level of public finance debt is so high that without high economic growth, it is practically impossible to reduce this debt quickly. Consequently, these types of countries are still vulnerable to the emergence of further economic crises should the current pace of economic growth slow 
down significantly. In order to improve this situation, the governments of individual countries are trying to activate entrepreneurship and innovation in their countries. However, this activation also requires spending further amounts of money from the state budget for pro-development purposes. However, this is necessary for the economic growth to improve, for incomes, consumption, investments to rise, for unemployment to fall, etc (DomańskaSzaruga, Prokopowicz, 2015, pp. 41-42).

Thanks to this type of effectively carried out activation of entrepreneurship, creation of facilities for the development of economic entities it is possible to effectively reduce the level of debt in the long term both in microeconomic terms in individual economic entities, as well as in macroeconomic terms, i.e. in the situation of an analysis of the systemic debt risk in the entire economy and in relation to the state of debt of public finances of the state.

The authors of this article examine this issue in correlation with the issue of improving credit risk management in financial institutions (Sarnowski, Prokopowicz, Dmowski, 2008, s. 253). The mistakes made in many economic entities and institutions, including public ones, also in central banking, led to a significant increase in the crediting of consumption, purchase of flats and houses, business ventures and new investment projects before 2008 and led to the largest global financial crisis in the history of economic development of the world. Therefore, it is necessary to constantly improve the credit risk management process as well as the management of other categories of risk: financial, banking, market, operational, IT systems, etc (Soboń, Prokopowicz, 2018, pp. 263-277).

Another important issue that should be taken into account in these considerations is the issue of improvement of the system of institutional control and combating corruption in the context of the impact of this process on economic growth. The experience of many countries in the field of improving the system of institutional control and combating corruption may have a significant impact on economic growth. In many developing countries, there were situations such as improvement of the efficiency of the tax system, tightening the tax system, reducing the shadow tax zone, and as a result of these activities, tax revenues to the state budget increased significantly from year to year (Ostrowska, 2013, p. 69). Then the state could implement pro-investment projects in the public 
sector to a greater extent, provide support to private sector companies, and develop social programs for citizens. In this way, economic growth improved significantly in the following years.

I have described an example of the development of pro-social programs and their positive impact on economic growth in my publications on social and economic policy programs, i.e. the Family 500 Plus program and the Mieszkanie Plus Program. The process of digitization of public offices, including the development and implementation of Internet technology, ICT and Industry 4.0 in public sector offices, helps in sealing the tax system, e.g. in terms of VAT collection and the requirement to introduce cash registers for various types of services. In a situation where entrepreneurs may or must handle all tax and other matters via the Internet, this increases the possibility of increasing the effectiveness of the tax system, including the automation of control processes. On the other hand, in highly developed economies, ICT, Internet and Industry 4.0 information technologies are already used at a high level of development, so the possible scope of improving the efficiency of the tax system is usually smaller than in developing countries, where these technologies are often at an early stage of development and are only now implemented in public offices. But this is only one of many elements differentiating individual developing and/or highly developed countries in the context of improving the efficiency of the tax system, including sealing this system, reducing the gray tax zone in order to increase tax revenues to the central state budget within the state public finance system and budgets of local self-government units (Brdulak ed., 2009, p. 38). 
Figure 2.

Income support during the COVID-19 pandemic, May 27, 2021. Income support captures if the government is covering the salaries or providing direct cash payments, universal basic income, or similar, of people who lose their jobs or cannot work.

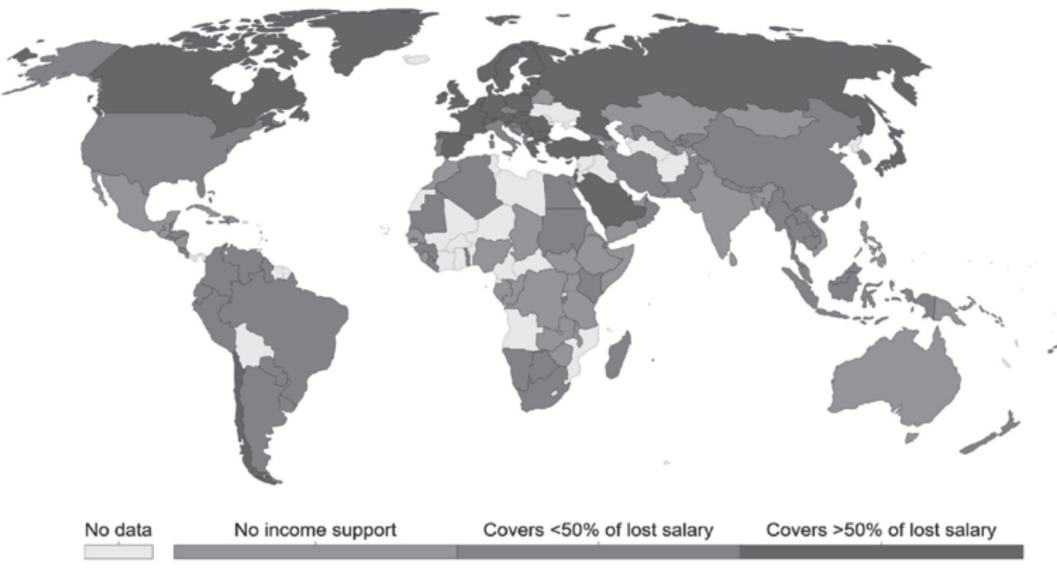

Source: Hale, Angrist, Goldszmidt, Kira, Petherick, Philips, Webster, Cameron-Blake, Hallas, Majumdar, Tatlow (2021). A global panel database of pandemic policies (Oxford COVID-19 Government Response Tracker), in: Nature Human Behaviour, last updated 27 May, 2021 (https://ourworldindata.org/covid-income-support-debt-relief). This income suport May not apply to workers in all sectors, and May vry At the sub-national level.

In addition, as regards the tightening of the tax system, the domestic issue should also include the international approach to tax issues. And so, many large enterprises, transnational corporations establish their headquarters in the socalled tax havens, i.e. in countries where taxes are much lower. This problem concerns not only developing, but also developed countries. The development of globally operating corporations should force the unification of tax systems internationally. This is happening, for example, in the European Union, where in this way, from a supra-national perspective, attempts are made to improve the operation of national tax systems in individual Member States of the European Union (Chojan, Grzegorek, Matosek, Prokopowicz, 2018, pp. 347-348). But unfortunately the European Union is only a smaller part of the global economy. Globalization processes have an increasing impact on tax issues analyzed and studied from a supra-national perspective. 
Economic growth should be based on a fair distribution of income and the active role of individual social groups in participation in this economic growth, in contributing to this growth and taking advantage of its effects. We know many situations from history where the generated economic growth was being created unfairly or the economic effects were not distributed, allocated fairly to individual social groups in society, and such a situation led to revolutions, political upheavals, etc. In the 21st century, economic growth will change by taking into account to a greater and greater extent the implementation of sustainable development goals, increasing the role and scale of application of environmental policy, pro-ecological state intervention, increasing the scale of the pro-environmental transformation of the classic economy towards a sustainable, green circular economy (Ngan, How, Teng, Promentilla, Yatim, Er, Lam, 2019, pp. 314-331). For economic growth in the 21 st century to improve the living conditions of people, it is necessary to increase international economic cooperation, including cooperation between highly developed countries and the developing and the poorest countries.

The cooperation should be implemented in such a way that all countries develop, and people's living conditions improve in all countries. Moreover, in the twenty-first century, economic growth is largely based on modern technologies and innovations that contribute to the improvement of the processes of production of goods, increase in income and improvement of the material situation of citizens. Due to the increasing level of environmental pollution, diminishing resources of clean water, increasing greenhouse gas emissions, etc., it is necessary to develop and increase the application of environmental policy, implementation of the sustainable development goals, etc. Thanks to this, the living conditions of people can be improved, or at least the scale of negative effects of the development of civilization will be reduced (Jessop, 2011). 


\section{Potential CLIMATE CRISIS AND INCREASE OF GENERAL SOCIAL PRO-ENVIRONMENTAL AWARENESS OF CITIZENS}

As far as long-term forecasts of the progressing global warming process for the next few decades are concerned, the estimates are different. However, it is certain that the process of unfavorable climate change has accelerated over the last several decades. Due to the growing amount of greenhouse gases in the atmosphere, the next few decades are the key period. There is little time left for the pro-ecological transformation of the classic economy to a sustainable, green circular economy in order to counteract adverse climate changes and reduce the scale of the risk of a potential climate crisis (The 17 Global Goals for Sustainable Development, 2020). According to various research centers analyzing the progressive climate change and the factors causing these changes, there is only 1 to 3 decades of time left to efficiently and quickly carry out a pro-ecological transformation of the economy, consisting primarily of replacing classic energy sources based on the combustion of fossil fuels with renewable, zero-emission energy sources (Shahbaz, Hye, Tiwari, Leitão, 2013, pp. 109-121). In addition, the process of full pro-environmental transformation of the transport sector should be completed through the development of electromobility, including, in particular, the development of power supply for motor vehicles based on the combustion of hydrogen with oxygen.

As part of the implementation of the sustainable development goals, reduction of environmental pollutant emissions and the reduction of greenhouse gas emissions, it is also necessary to develop sustainable ecological agriculture, improve waste segregation and recycling techniques, etc (Sustainable Development Goals, 2020). Without the implementation of this pro-environmental plan on a global scale, by the middle of the 21 st century at the latest, the amount of greenhouse gases in the atmosphere will exceed the tipping point, the global warming process will accelerate even more and become irreversible. If this pessimistic scenario were to be realized, there will be a climate crisis (COP 25 Climate Conference in Madrid, 2019) at the end of the 21st century at the latest, which will mean a multiple increase compared to the present state of the following phenomena: weather anomalies and climate 
and natural disasters, droughts, fires, scarcity of clean water, volcanic eruptions and other unfavorable effects of climate change and, as a consequence of these processes, also the continuation of the accelerating global warming process, etc. Humanity should therefore do everything possible to counteract this pessimistic scenario.

Figure 3.

Interplay of the environmental, economic, and social aspects of sustainable development. Mark Fedkin. Adopted from the University of Michigan Sustainability Assessment, Rodriguez et al., 2002.

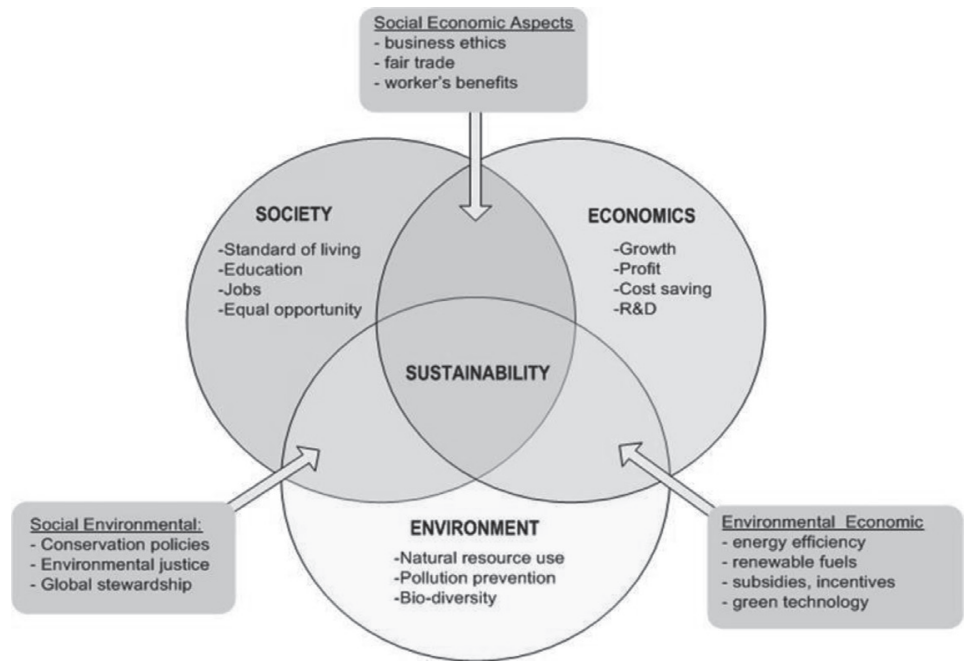

Source: Utama I, Utama M. (2019). The Political Law on Coal Mining in the Fulfilment of People's Welfare in Indonesia, (in:) "Sriwijaya Law Review", Vol. 3 Issue 1, January 2019, pp. 11-25, (http://journal.fh.unsri. ac.id/index.php/sriwijayalawreview; https://www.researchgate.net/publication/330762891_The_Political_ Law_on_Coal_Mining_in_the_Fulfilment_of_People\%27s_Welfare_in_Indonesia).

The key positive aspects of the SARS-CoV-2 (Covid-19) coronavirus pandemic include environmental (pro-ecological) issues, including a decrease in the level of environmental pollution that occurred mainly during the 1st wave of the pandemic in 2020. Many positive aspects of the pandemic were also diagnosed in terms of changing people's lifestyle. For example, an increased interest in a healthy lifestyle in order to strengthen the overall immunity of the body has been observed among people. Some smokers have quit smoking. Many people began to eat healthier foods and devote more time to physical 
activity. Besides, staying in the recommended home quarantine, they could devote more time to the family. Some people who were not vaccinated for influenza in the fall-winter $2020 / 2021$ season decided to get vaccinated to minimize the risk of complications caused by influenza and other comorbidities if they were infected with the SARS-CoV-2 coronavirus. In addition, a significant proportion of people planned to get vaccinated against the coronavirus as soon as such an opportunity appeared already in 2020. In 2021, along with progressive vaccination programs, the number of people choosing to vaccinate against coronavirus has grown rapidly. Many positive aspects resulting from the pandemic can be distinguished in the field of environmental protection, increasing environmental awareness and leading a healthy lifestyle. However, the scale of these processes was not large.

Figure 4.

The level of differentiation in the implementation of the principles of sustainable development. Global Green Economy Index, 2018 (in percentile 0-1, higher = better).

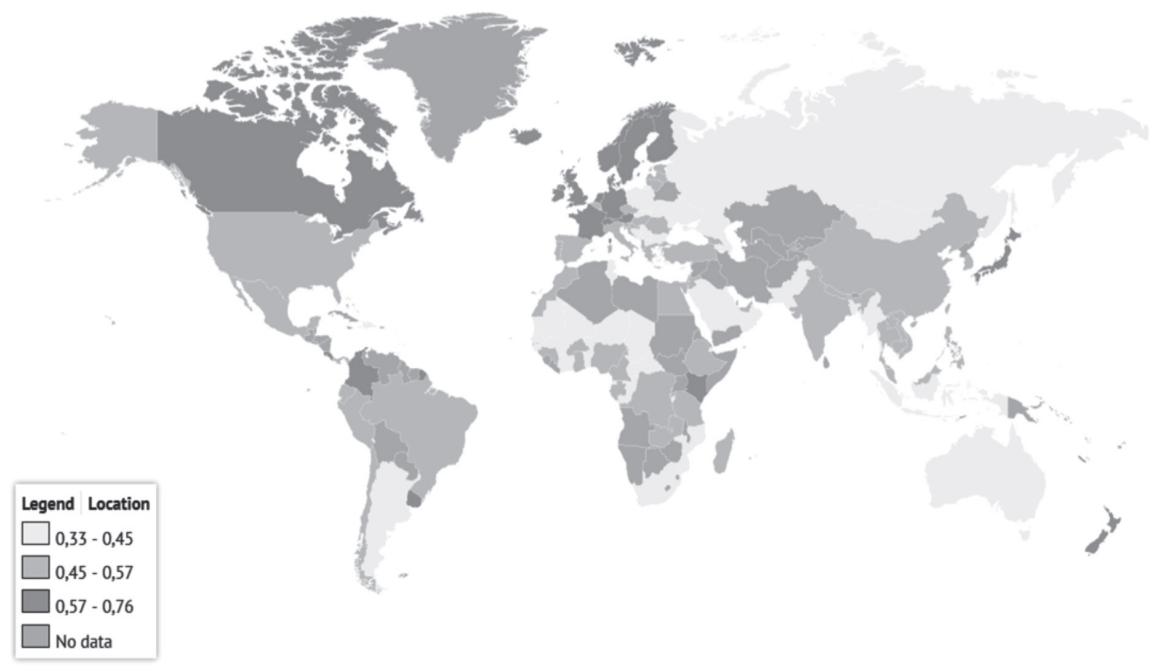

Source: Global Green Economy Index, 2018, (in:) “Knoema.com” website, Data Driven, March 11, 2019, (https:// knoema.com/infographics/enedcw/global-green-economy-index-2018), access: 15.5.2021. 
From July 2020, the prod-pandemic state in 2021. Therefore, the period of reduced greenhouse gas emissions, caused by reduced demand for energy production in industry, services and transport, as well as a decline in pollutant emissions to the natural environment, ended gradually at the end of 2020 or in the first quarter of 2021. The period of decline in environmental pollution was therefore relatively short. However, in many parts of the world, in various natural ecosystems, the positive effects of the decline in environmental pollution and the revival of nature could be observed. This period was an excellent opportunity to accelerate the processes of increasing the scale of achieving the goals of sustainable development (Štrukelj, Nikoli'c, Zlatanovi 'c, Zabukovšek, 2020, p. 526). In the anti-crisis programs of interventionist instruments of socio-economic policies, including the socalled anti-crisis shields, the financing of pro-ecological economic reform projects has unfortunately not increased significantly. It is a pity that the opportunities that appeared during the pandemic were not used in this matter. During the pandemic, there were opportunities to accelerate the processes of implementing the principles of sustainable development, promoting social environmental (ecological) responsibility, pro-ecological reforms in implementing eco-innovation into economic processes, etc (Bocken, Short, Rana, Evans, 2014, pp. 42-56).

In view of the above, the coronavirus pandemic indirectly increased the importance of the implementation of the Sustainable Development Goals and also increased the scale of general social awareness of the pro-environmental issues. People became more interested in a healthy lifestyle, they began to contemplate to a greater extend the issue of relationship between the human and the surrounding natural environment, relations with nature, the issue of sustainability, the protection of biodiversity of natural ecosystems, and restoring the balance between the development of civilization and the biosphere and climate of the planet Earth (Blicharska, Smithers, Mikusiński, Rönnbäck, Harrison, Nilsson, Sutherland, 2019). On the other hand, the level of economic activity and the demand for raw materials decreased during the coronavirus pandemic, including classic energy materials based on burning fossil fuels. During the first wave of the pandemic, reductions in greenhouse gas emissions and environmental pollution were noticed in many industrialized, urbanized, 
transformed, etc. places. The opportunity to accelerate the pro-ecological transformation of the economy occured, including the pro-ecological transformation of the energy sector through the development of zero-emission energy based on renewable energy sources (Bridle, Kitson, 2014).

Figure 5.

Pro-ecological transformation of the economy-different levels in individual countries. Biggest Movers in Climate Change Adaptation (Change in Notre Dame Global Adaptation Index ND-GAIN from 1995 to 2017).

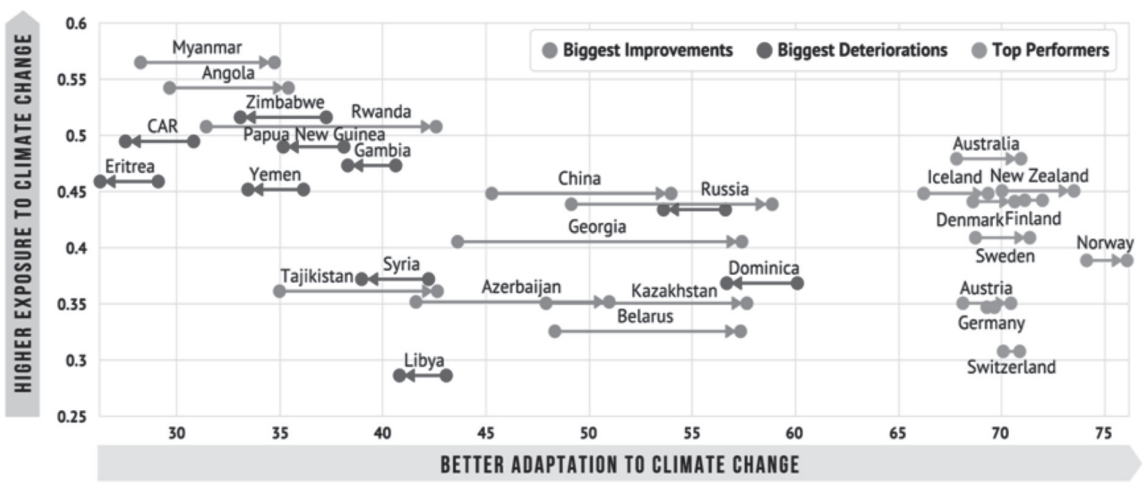

Source: Adapting to Climate Change: How Ready is Your Country?, (in:) "Knoema.com" website, Data Driven, January 15, 2020, (https://knoema.com/infographics/wemjthe/adapting-to-climate-change-how-readyis-your-country), for: Notre Dame Global Adaptation Initiative, access: 15.5.2021.

The possibilities of implementing the principles of sustainable development, the implementation of pro-ecological activities taking into account social environmental responsibility, the creation and implementation of eco-innovations in economic processes, etc. have increased. Therefore, the Coronavirus pandemic created the conditions for accelerating the processes of pro-ecological transformation of the traditional, classical, brown economy to a zero-emission, sustainable, green circular economy (Masi, Day, Godsell, 2017, p. 1602), but unfortunately these opportunities were not taken advantage of. Yet, public financial aid as part of anti-crisis interventionist programs of the socio-economic, fiscal, budgetary and monetary policy, was offered to economic entities operating in various industries and sectors of the economy, regardless of whether they acted 
pro-ecologically or not. The aim of the aforementioned public financial aid, which was based on supporting commercially operating companies and enterprises, was to activate economic processes and limit the scale of unemployment growth. The goals of sustainable development and the possibilities of accelerating the processes of building a sustainable, green circular economy have been almost completely ignored (Global Green Economy Index, 2018, 2019) in some countries as part of the anti-crisis socio-economic policy. The aim was to activate economic processes, regardless of whether certain economic entities implement eco-innovations and strive to achieve the goals of sustainable development or not.

The European Union is an economic organism that is at the fore in creating a long-term strategy for the implementation of the pro-environmental transformation of the economy and the gradual increase in the implementation of sustainable development goals. For example, in terms of reducing the scale of environmental pollution with plastic waste. The use of plastics, including plastic materials, in the packaging of various products has grown rapidly in recent years (Mbeng, Phillips, Fairweather, 2009, pp. 27 - 36). Some countries are already adopting recommendations or normative regulations aimed at limiting the use of plastics in packaging while replacing them with biodegradable materials, e.g. made from agricultural crops. In the European Union, the use of plastic in packaging is allowed by norm until 2021. It is an important systemic action, the aim of which is to mobilize the industry to apply specific measures, pro-ecological reforms, to activate research institutes dealing with material technologies to create biodegradable substitutes replacing plastic packaging, and to ecological innovations enabling the economic application of these pro-ecological activities. Therefore, it is an important systemic element of the implementation of the principles of sustainable development and the next step towards the development of the economy in accordance with the concept of a sustainable, green circular economy. Similarly, in terms of reducing greenhouse gas emissions, year on year, the European Commission issues new regulations and normative documents, according to which the process of gradual reduction of greenhouse gases will proceed faster and faster (Pakulska, 2018, pp. 1131-1138). 


\section{THE CURRENT PANDEMIC CRISIS AND COUNTERACTING THE FUTURE CLIMATE CRISIS}

The current period of recovery from the economic crisis caused by the SARS-CoV-2 (Covid-19) coronavirus pandemic is a very good opportunity to accelerate the process of pro-environmental transformation of the classic, traditional economy towards a sustainable, green circular economy. The current period, i.e. the year 2021, the year of recovering from the slowdown in economic development, economic downturn, decline in economic activity in many service sectors of the economy, is a very good time to accelerate the process of pro-environmental transformation of the economy, increase outlays from the state finance system to carry out pro-ecological reforms, increase the scale of implementation of sustainable development goals, pro-ecological reforms, implementation of eco-innovation (Pakulska, 2020, pp. 63-64) to economic processes, including pro-ecological transformation of the energy sector mainly through the development of renewable energy sources, improvement of waste segregation techniques and recycling, development of sustainable ecological agriculture, development of electromobility, increase in the scale of pro-environmental state interventionism and social environmental (ecological) responsibility (Prokopowicz, 2020b, pp. 427-428). This process has already begun. The creation of a special fund called the European Reconstruction Fund at the European Commission in an example of this process. A significant part of the project of anti-crisis funds worth around EUR 750 billion, which, in the European Union, will be allocated to support the recovery of the European economies from the economic recession caused by the pandemic, is also to be allocated for co-financing the implementation of pro-environmental economic ventures (Jänicke, 2011). 
Chart 5.

Average global temperature rise from 1961-1990 in degrees Celsius $\left({ }^{\circ} \mathrm{C}\right)$. The red line represents the median of the mean temperature change and the gray lines represent the upper and lower $95 \%$ confidence intervals.

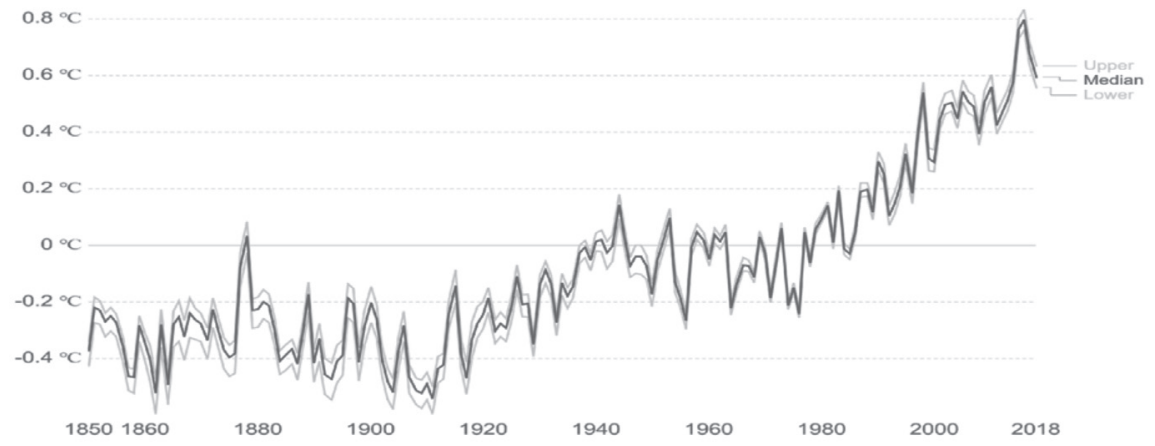

Source: H. Ritchie, M. Roser, CO2 and other Greenhouse Gas Emissions (in:) Portal internetowy "Our World in Data", May 2017, (https://ourworldindata.org/co2-and-other-greenhouse-gas-emissions), for: Hadley Centre (HadCRUT4).

In the period December 2020-January 2021, at the summit of the prime ministers of the European Union Member States, key strategic goals were set for accelerating the process of reducing greenhouse gas emissions and the related processes of the necessary transformation of the energy sector, the development of electromobility not only in land transport, but also in sea and air transport, etc. for the medium-term perspective of the next decade and the long-term perspective until 2050, i.e. the year of achieving full climate neutrality in the European Union (The UN Climate Change Conference COP 25 , 2019). Recently, several countries, including China and Japan, have adopted a similar plan to achieve full climate neutrality by 2050 . In connection with the above, the processes of the pro-environmental transformation of the economy accelerated. However, there is still an opinion that they are too slow in the context of the pace of the progressing global warming process, the extinction of flora and fauna, including the rapid pace of extinction of pollinating insects, the increasing level of environmental pollution, the decline in biodiversity, declining forest areas, and more and more frequent forest fires, increasingly severe droughts on farmlands, diminishing resources of clean water, melting glaciers, degradation of the natural ecosystems of planet Earth, etc. 


\section{REFERENCES}

Adapting to Climate Change: How Ready is Your Country? (2020) in: "Knoema.com" website, Data Driven, January 15, 2020, (https://knoema.com/infographics/wemjthe/ adapting-to-climate-change-how-ready-is-your-country), for: Notre Dame Global Adaptation Initiative, access: 15.5.2021.

Białas, M., Mazur, Z. (2013). Bankowość wczoraj i dziś. Warsaw: Publishing House Difin. Blicharska, M., Smithers, R. J., Mikusiński, G., Rönnbäck, P., Harrison, P. A., Nilsson, M., Sutherland, W. J. (2009). Biodiversity's contributions to sustainable development (in:) „Nature Sustainability”, November 2019, (https://www.researchgate.net/publication/337522739; https://rdcu.be/bXARU).

Brdulak J. J. ed. (2009). Zarządzanie w jednostkach sektora finansów publicznych. Kierunki zmian, Warsaw: Publishing House SGH.

Bridle, R., Kitson, L. (2014). The Impact of Fossil-Fuel Subsidies on Renewable Electricity Generation. IISD, Winnipeg. (http://www.iisd.org/gsi/sites/default/files/ffs_rens_impacts.pdf).

Bocken, N. M., Short, S. W., Rana, P., Evans, S. (2014). A literature and practice review to develop sustainable business model archetypes, (in:) „Journal of Cleaner Production”, No. 65, 2014, pp. 42-56, (https://doi.org/10.1016/j.jclepro.2013.11.039).

Chojan, A., Grzegorek, J., Matosek, M., Prokopowicz, D. (2018). The development of the banking system in Poland determined by the processes of adjustment to the normative and technological standards of The European Union and contemporary processes of economic and informational globalization, (in:) „International Journal of Legal Studies”, Międzynarodowy Instytut Innowacji „Nauka - Edukacja - Rozwój” In Warsaw, Warsaw, December 2018, No. 2 (4) 2018, pp. 339-367.

COP 25 Climate Conference in Madrid. (2019) in: "ClimateCake.pl" website, News, Center for Climate and Energy Analysis, December 2019, (http://climatecake.pl/ aktualnosci/life-climate-cake-pl-konferencji-klimatycznej-cop-25-madrycie), access: 12.5.2021.

Dahl, M., Prokopowicz, D., Gwoździewicz, S., Grzegorek, J. (2018). Application of data base systems Big Data and Business Intelligence software in integrated risk management in organization (in:) "International Journal of New Economics and Social Sciences”, Międzynarodowy Instytut Innowacji „Nauka-Edukacja-Rozwój”, No. 2 (8) 2018, Warsaw, December 2018, s. 43-56.

Dmowski, A., Prokopowicz, D. (2006). Przestępczość elektroniczna i kradzież poufnych informacji - dynamicznie rozwijająca się gałaź szarej strefy (in:) „Szara strefa gospodarcza w dobie globalizacji”, Seria wydawnicza: Konferencje i seminaria nr 19, Prywatna Wyższa Szkoła Businessu i Administracji in Warsaw, Warsaw 2006, pp. 76-96. 
Dmowski, A., Prokopowicz, D. (2010). Rynki finansowe, Warsaw: Publishing House: Centrum Doradztwa i Informacji Difin sp. z o.o., .

Domańska-Szaruga, B., Prokopowicz, D. (2015). Makroekonomiczne zarządzanie antykryzysowe (in:) 34 Zeszyty Naukowe Uniwersytetu Przyrodniczo Humanistycznego w Siedlcach, No. 107, Seria: Administracja i Zarządzanie (34) 2015, UPH Wydział Nauk Ekonomicznych i Prawnych, Siedlce 2015, pp. 37-48.

Domańska-Szaruga, B., Prokopowicz, D. (2016). Ochrona transferu danych osobowych $w$ cyberprzestrzeni (in:) „Secretum. Służby specjalne, bezpieczeństwo i informacja", Instytut Nauk Społecznych i Bezpieczeństwa Uniwersytetu PrzyrodniczoHumanistycznego w Siedlcach, Oficyna Wydawnicza RYTM w Warszawie, No. 2(5)/2016, pp. 122-136.

Filip, D. (2015). Big Data - narzędzie instytucji finansowych $w$ dotarciu do klienta, (in:) "Ekonomia - Wroclaw Economic Review", No. 21/3 (2015), Wrocław: Acta Universitatis Wratislaviensis, pp. 39-53.

Filip, D., Komorowski, P. (2016). Konkurencyjność rynków finansowych. Czynniki efektywności, (in:) "Przedsiębiorstwo \& Finanse”, No. 2/2016 (13), Białystok, pp. 61-75. Global Green Economy Index, 2018 (2019) in: "Knoema.com" website, Data Driven, March 11, 2019, (https://knoema.com/infographics/enedcw/global-green-economy-index-2018), access: 15.5.2021.

Golczak, K., Golinowski, K., Kamycki, J., Lewandowski, K. J., Pająk, K., Płaczek, J., Prokopowicz, D., Wesołowski, Z. (2020). Prognoza globalnego kryzysu finansowo-gospodarczego zdeterminowanego przez pandemię koronawirusa w obszarze gospodarczym, społecznym, politycznym i geopolitycznym. Prognoza kryzysu w obszarze gospodarczym (in:) P. Soroka, A. Skrabacz, P. Wilczyński, K. Golczak, R. Kołodziejczyk, K. Pająk, A. Mitrega (ed.) Raport zawierający diagnoze i prognoze globalnego kryzysu finansowo-gospodarczego zdeterminowanego przez pandemie koronawirusa w obszarze gospodarczym, społecznym, politycznym i geopolitycznym, Warsaw: Publishing House Elipsa, pp. 87-120.

Górski, M. (2013). Rynkowy system finansowy, Warsaw: Publishing House PWE.

Grzegorek, J., Prokopowicz, D., Goździewicz, S. (2021). Wykorzystanie platform analitycznych Big Data Analytics technologii informacyjnych ICT w analizie sentymentu dla wybranej problematyki zwiazanej z Przemystem 4.0, (in:) P. J. Suwaj, S. Goździewicz, K. Samulska (ed.), Bezpieczeństwo informacyjne jednostek organizacyjnych. Wybrane problemy, Gorzów Wielkopolski: Publishing House Akademia im. Jakuba z Paradyża w Gorzowie Wielkopolskim, pp. 101-142.

Gwoździewicz, S., Prokopowicz, D. (2015). Administrative, supervisory and legal determinants of globalization of financial markets and the banking system in Poland (in:) "International Journal of New Economics and Social Sciences", International 
Institute of Innovations “Science-Education-Business" in Warsaw, No. 2 (2) 2015, pp. 203-216.

Gwoździewicz, S., Prokopowicz, D. (2016a). Globalization and the process of the system and normative adaptation of the financial system in Poland to the European Union standards (in:) Globalization, the State and the Individual, "International Scientific Journal”, University of Varna “Chernorizets Hrabar”, Chayka, Varna, Bułgaria 9007, Varna 2016, No. 1(9) 2016, pp. 63-75.

Gwoździewicz, S., Prokopowicz, D. (2016b). Prawno-społeczne determinanty bezpieczeństwa gromadzenia i transferu danych niejawnych w internetowych portalach społecznościowych (in:) V. Vlastimil (ed.), "Međunarodni naučni zbornik. Pravo Ekonomija Menadžment I", International Scientific Books. Right, Economy and Management I, Izdavač: Srpsko Razvojno Udruženje, Bački Petrovac, pp. 80-107.

Gwoździewicz, S., Prokopowicz, D. (2020). Analysis of the security of information systems protection in the con-text of the global cyberatacs ransomware conducted on June 2, 2017, Chapter 4, (in:) S. Gwoździewicz, K. Tomaszycki (ed.), Legal and Social Aspects of Cybersecurity, Warsaw: Difin Publisher, pp. 60-79.

Harold, J. (2010). Koniec globalizacji. Czego nauczył nas wielki kryzys?, Warsaw: Publishing House Scholar.

Hale, Angrist, Goldszmidt, Kira, Petherick, Philips, Webster, Cameron-Blake, Hallas, Majumdar, Tatlow. (2021). A global panel database of pandemic policies (Oxford COVID-19 Government Response Tracker), in: Nature Human Behaviour, last updated 27 May, 2021 (https://ourworldindata.org/covid-income-support-debt-relief). This income suport May not apply to workers in all sectors, and May vry At the sub-national level.

Jänicke, M. (2011). Green Growth: From a Growing Eco-industry to a Sustainable Economy, Freie Universität Berlin, Berlin.

Jessop, B. (2011). The Global Economic Crisis, the Green New Deal, and the No-Growth Economy, Conference of UNRISD.

Karaś, D. (2017). Shapley value as a measurer of shareholders decision power, (w:) "World Scientific News", No. 90/2017, pp. 231-242.

Kontkiewicz - Studzińska, J., Cieślak, R. (2021). Digitalizacja polskich firm przemysłowych $w$ dobie pandemii, Raport 2021, Wydawnictwo Autodesk, May 2021, (www. autodesk.pl/Przemysl2021).

Kołodko, G., Mihm, S., Roubini, N. (2011). Ekonomia kryzysu, Warsaw: Publishing House Wolters Kluwer Polska.

Matosek, M., Prokopowicz, D. (2017). Importance And Security OfInformation Provided By The Internet In The Context Of The Development Of Economic Entities In Poland (in:) "International Journal of New Economics and Social Sciences”, Warszawa: Międzynarodowy Instytut Innowacji „Nauka-Edukacja-Rozwój”, No. 2 (6) 2017, pp. 219-231. 
Matosek, M., Prokopowicz, D. (2018). Szanse i bariery wielokulturowości jako aspektu organizacyjnego międzynarodowej współpracy rozwojowej w Unii Europejskiej (in:) "Uniwersyteckie Czasopismo Socjologiczne. Academic Journal of Socjology", Instytut Socjologii, Wydział Nauk Historycznych i Społecznych UKSW, No. 23 (2) 2018, pp. 29-40.

Matysek-Jędrych, A. ed. (2011). Instytucje i rynki wobec kryzysu finansowego - źródła i konsekwencje kryzysu, Warsaw: Publishing House CeDeWu.

Masi, D., Day, S., Godsell, J. (2017). Supply chain configurations in the circular economy: A systematic literature review, (in:) „Sustainability”, No. 9(9) 2017, p. 1602.

Mbeng, L. O., Phillips, P. S., Fairweather, R. (2009). Developing sustainable waste management practice: application of q methodology to construct new strategy komponent in Limbe e Cameroon, (in:) „The Open Waste Management Journal”, No. 2, 2009 , pp. $27-36$.

Nawrot, W. (2009). Globalny kryzys finansowy XXI wieku. Warsaw: Publishing House CeDeWu, p. 58.

Ngan, S. L., How, B. S., Teng, S. Y., Promentilla, M. A. B., Yatim ,P., Er A. C., Lam, H. L. (2019). Prioritization of sustainability indicators for promoting the circular economy: The case of developing countries, (in:) „Renewable and Sustainable Energy Reviews”, No. 111, pp. 314-331.

Ostrowska, D. (2013). System nadzoru i bezpieczeństwa na rynku finansowym w Polsce, Warsaw: Publishing House Difin.

Pakulska, J. (2018). Diversification of eco-innovation in the EU Member States, (in:) Staničkova M., Melecky L., Kovařova E., Dvorokova K. (ed.), Proceedings of the 4th International Conference on European Integration 2018, Ostrava: Technical University of Ostrava, pp. 1131-1138.

Pakulska,J. (2020). Nakłady na innowacje ekologiczne w krajach Unii Europejskiej w latach 2010-2018, (in:) „Studia Ecologiae et Bioethicae”, July 2020, No. 18, 2, pp. 57-70.

Piech, K., Wierus, K. (2012). Ostatni światowy kryzys finansowy. przyczyny, przebieg, polityka, przedsiębiorstwa, Warsaw: Publishing House Instytut Wiedzy i Innowacji.

Prokopowicz, D. (2012). Globalizacja, współpraca międzynarodowa $i$ handel zagraniczny. Sięgając w przeszłość (in:) "Przedsiębiorstwo przyszłości”. Quarterly Wyższej Szkoły Zarządzania i Prawa im. Heleny Chodkowskiej. Warszawa, No. 1 (10) 2012, January 2012, edition IV, pp. 37-48.

Prokopowicz, D. (2016). Social and economic determinants of the processes of economic globalization that shape the development of the banking system in Poland (in:) Globalization, the State and the Individual, "International Scientific Journal", Free University of Varna "Chernorizets Hrabar", Chayka, Varna, Bułgaria 9007, No. 2(10) 2016, pp. 19-32. 
Prokopowicz, D. (2018). Determinants of the normative improvement of prudential instruments of the financial system in Poland (in:) „International Journal of Legal Studies”, Międzynarodowy Instytut Innowacji „Nauka - Edukacja - Rozwój” w Warszawie, Warszawa, June 2018, No. 1 (3) 2018, pp. 155-178.

Prokopowicz, D. (2020a). Analysis of the effects of post-2008 anti-crisis mild monetary policy of the Federal Reserve Bank and the European Central Bank (in:) "International Journal of Small and Medium Enterprises and Business Sustainability", volume 5, No. 1, 13 March 2020, Center for Industry, SME and Business Competition Study, Faculty of Economics, Trisakti University in Jakarta, Indonesia. University of Social Sciences, Warsaw, Poland, pp. 1-35.

Prokopowicz, D. (2020b). Implementation of The Principles of Sustainable Economy development as a key element of Pro-ecological transformation of The Economy towards Green Economy and Circular Economy (in:) "International Journal of New Economics and Social Sciences", Międzynarodowy Instytut Innowacji Nauka - Edukacja - Rozwój In Warsaw, No. 11 (1) 2020, pp. 417-480.

Prokopowicz, D., Gwoździewicz, S. (2016). Prawo do ochrony informacji $i$ danych osobowych $w$ cyberprzestrzeni $w$ dobie rozwoju bankowości internetowej - The Right to Protection of Information and Personal Data in the Cyberspace in the Age of the Internet Banking Development (in:) D. Gałuszka, G. Ptaszek, D. Żuchowska-Skiba (ed.), “Technologiczno-społeczne oblicza XXI wieku”, Kraków: Publishing House LIBRON Filip Lohner, pp. 391-419.

Prokopowicz, D., Gwoździewicz, S. (2017). The Big Data technologies as an important factor of electronic data processing and the development of computerized analytical platforms, Business Intelligence (in:) "International Journal of Small and Medium Enterprises and Business Sustainability”, volume 2, issue 4, November 2017, Center for Industry, SME and Business Competition Studies, University of Trisakti in Jakarta, Indonesia, University of Social Sciences in Warsaw, pp. 27-42.

Prokopowicz, D., Gwoździewicz, S. (2018). Regulated normatively anti-cyclical, anti-crisis, domestic monetary policy of central banking in Poland (in:) „International Journal of Legal Studies”, Warsaw: Międzynarodowy Instytut Innowacji „Nauka - Edukacja - Rozwój”, June 2018, No. 1 (3) 2018, pp. 215-232.

Prokopowicz, D., Gwoździewicz, S. (2019). The Importance and Organization of Business Information Offered to Business Entities in Poland via the Global Internet Network (in:) "International Journal of Small and Medium Enterprises and Business Sustainability”, volume 4, No. 2, July 2019, Center for Industry, SME and Business Competition Study, Faculty of Economics, Trisakti University in Jakarta, Indonesia. University of Social Sciences in Warsaw, pp. 25-43.

Przybylska-Kapuścińska, W. ed. (2013). Funkcjonowanie współczesnego rynku pieniężnego i kapitałowego, Warsaw: Publishing House CeDeWu. 
Ritchie, H., Ortiz-Ospina, E., Beltekian, D., Mathieu, E., Hasell, J., Macdonald, B., Giattino, Ch., Appel, C., Rodés-Guirao, L., Roser, M. (2021). Coronavirus Pandemic (COVID-19), Published online at OurWorldInData.org., Online Resource (Retrieved from: https://ourworldindata.org/coronavirus).

Ritchie, H., Roser, M. (2021). CO2 and other Greenhouse Gas Emissions (in:) Portal internetowy "Our World in Data", May 2017, (https://ourworldindata.org/co2-andother-greenhouse-gas-emissions), for: Hadley Centre (HadCRUT4).

Ritchie, H., Ortiz-Ospina, E., Beltekian, D., Mathieu, E., Hasell, J., Macdonald, B., Giattino, Ch., Appel, C., Rodés-Guirao, L., Roser, M. (2021). COVID-19: Stay-at-Home Restrictions, for: Hale, Angrist, Goldszmidt, Kira, Petherick, Philips, Webster, Cameron-Blake, Hallas, Majumdar, Tatlow (2021). A global panel database of pandemic policies (Oxford COVID-19 Government Response Tracker), in: Nature Human Behaviour, last updated 27 May, 2021 (https://ourworldindata. org/covid-stay-home-restrictions).

Sarnowski, J., Prokopowicz, D., Dmowsk, A. (2008). Finanse i bankowość. Teoria i praktyka, Warsaw: Publishing House Centrum Doradztwa i Informacji Difin sp. z o.o. Scholtens, B. (2009). Corporate social responsibility in the international banking industry, (in:) „Journal of Business Ethics”, Vol. 86, No. 2, 2009.

Shahbaz, M., Hye, Q. M. A., Tiwari, A. K., Leitão, N. C. (2013). Economic growth, energy consumption, financial development, international trade and CO2 emissions in Indonesia, (in:) „Renewable and Sustainable Energy Reviews”, Vol. 25, September 2013, pp. 109-121.

Soboń, J., Prokopowicz, D. (2018). Anti-crisis state intervention and created in media images of global financial crisis (in:) "International Journal of New Economics and Social Sciences”, Międzynarodowy Instytut Innowacji „Nauka-Edukacja-Rozwój” in Warsaw, No. 2 (8) 2018, December 2018, pp. 263-277.

Štrukelj, T., Nikoli'c, J., Zlatanovi'c, D., Sternad Zabukovšek, S. (2020). A Strategic Model for Sustainable Business Policy Development, (in:) „Sustainability”, No. 12(2020), p. 526; 10 January 2020, MDPI, (www.mdpi.com/journal/sustainability; doi:10.3390/ su12020526).

Sustainable Development Goals, (2020) in: „United Nations Development Programme. org" website, 2015-2020, (https://www.undp.org/content/undp/en/home/sustainable-development-goals.html), access: 12.5.2021.

Szybowski, D., Prokopowicz, D., Gwoździewicz, S. (2016). Activating interventionist monetary policy of the European Central Bank in the context of the security of the European Financial System (in:) "International Journal of New Economics and Social Sciences", International Institute of Innovations "Science-Education-Business" in Warsaw, No. 2 (4) 2016, pp. 138-146. 
The 17 Global Goals for Sustainable Development, (2020) in: "Global Goals.org" website, 2015-2020, (https://www.globalgoals.org; https://worldslargestlesson.globalgoals. org), access: 11.5.2021.

The UN Climate Change Conference COP 25 (2019) in: "UN Environment Programme" website, Overview, 2-13 December 2019, (https://www.unenvironment.org/events/ conference/un-climate-change-conference-cop-25), access: 14.5.2021.

Utama, I, Utama, M. (2019). The Political Law on Coal Mining in the Fulfilment of People's Welfare in Indonesia, (in:) "Sriwijaya Law Review", Vol. 3 Issue 1, January 2019, pp. 11-25, (http://journal.fh.unsri.ac.id/index.php/sriwijayalawreview; https://www. researchgate.net/publication/330762891_The_Political_Law_on_Coal_Mining_in_ the_Fulfilment_of_People\%27s_Welfare_in_Indonesia).

Wereda, W., Prokopowicz, D., Domańska-Szaruga,B. (2018). Globalizacyjne i normatywne determinanty procesu doskonalenia zarzadzania bankowym ryzykiem kredytowym $w$ Polsce, Globalizational and normative determinants of the improvement of the banking credit risk management in Poland (in:) „International Journal of Legal Studies”, Międzynarodowy Instytut Innowacji „Nauka - Edukacja - Rozwój” In Warsaw, Warsaw, December 2018, No. 2 (4) 2018, s. 257-293.

Wołowiec, W., Szybowski, D., Prokopowicz D. (2019). Methods of development network analysis as a tool improving efficient org, anization management. (in:) "International Journal of New Economics and Social Sciences", Międzynarodowy Instytut Innowacji „Nauka-Edukacja-Rozwój” in Warsaw, No. 1 (9) 2019, June 2019, pp. 229-249.

Zielińska-Głębocka, A. (2012). Wspótczesna gospodarka światowa, Warsaw: Publishing House Wolters Kluwer Polska. 